\title{
Efeito do extrato de tiririca no enraizamento de estacas de limão-Tahiti
}

\section{Effect of tiririca extract on rooting of lemon-Tahiti cuttings}

\author{
Daniel Henrique Santana Rodrigues ${ }^{\left({ }^{1}\right)}{ }^{1}$; Sara da Silva Abes ${ }^{\left(\mathbb{D}^{2}\right.}{ }^{2}$; Guilherme Henrique Fernandes ${ }^{\left(\mathbb{D}^{3}\right.}{ }^{3}$; João \\ Paulo Gomes dos Santos ${ }^{\left({ }^{4}\right.}{ }^{4}$; Antonio Cesar Costa ${ }^{\text {(D) }}$; Diógenes Martins Bardiviesso ${ }^{(0)}$
}

${ }^{1}$ Graduação em Agronomia, Universidade Estadual de Mato Grosso do Sul, Rodovia MS 306, Km 6,4, CEP: 79.540-000, Cassilândia, Mato Grosso do Sul, +5517991680541, $\quad$ daniel.h.s.r@hotmail.com; $\quad 3$ gfernandeshenriqueguilherme@gmail.com; 5 antonio_cesartereza@ hotmail.com; ${ }^{2}$ Professora da Universidade Estadual de Mato Grosso do Sul, sara.abes@gmail.com; ${ }^{6}$ bardiviesso@yahoo.com.br.

\section{NO T A \\ C I E N T Í F I C A}

Recebido: $27 / 10 / 2019$

Aprovado: 20/02/2020

Palavras-chave:

Fitormônio;

Cyperus rotundus L.

Citrus latifolia Tanaka

Propagação

\section{R E S U M O}

O tratamento de estacas com extrato de tiririca (Cyperus rotundus L.) tem sido recomendado como alternativa para estimular o enraizamento de várias espécies, devido sua eficiência e baixo custo, contudo, pesquisas envolvendo métodos alternativos para estimular o enraizamento de estacas de limão-Tahiti (Citrus latifolia Tanaka) são escassas. Portanto, o objetivo foi avaliar os efeitos de uma técnica alternativa de propagação de mudas de estacas de limão-Tahiti por meio de enraizamento, com o uso de extrato de tiririca. O delineamento experimental utilizado foi de blocos ao acaso, com cinco tratamentos e quatro repetições. Os tratamentos foram compostos por testemunha (estacas tratadas com água destilada) e tratamento de estacas com quatro extratos de tiririca, nas concentrações de: $75 \mathrm{~g} / \mathrm{L}(25 \%), 150 \mathrm{~g} / \mathrm{L}$ (50\%), $225 \mathrm{~g} / \mathrm{L}$ (75\%) e $300 \mathrm{~g} / \mathrm{L}(100 \%)$. Cada unidade experimental foi constituída por seis estacas. As avaliações foram realizadas 90 dias após o plantio, sendo mensurados os seguintes parâmetros: porcentagem de estacas enraizadas; número de raízes por estaca; comprimento das três maiores raízes por estaca; porcentagem de estacas com calos; porcentagem de estacas vivas; porcentagem de estacas não viáveis; quantidade de folhas por estacas; massa verde (\%) e massa seca $(\%)$. O extrato de tiririca não influenciou o enraizamento das estacas de limão-Tahiti. Percentuais de estacas vivas foram significativamente maiores na concentração de $225 \mathrm{~g} / \mathrm{L}$ (75\%), indicando que o extrato não exerceu efeito alelopático sobre o desenvolvimento e sobrevivência das estacas. Contudo, faz-se necessário estudos, para verificar a concentração ideal do extrato para o enraizamento de estacas de limão-Tahiti.

\section{A B S T R A C T}

The treatment of cuttings using tiririca extract (Cyperus rotundus L.) has been recommended to stimulate the rooting of many species, due to its efficiency and low cost as well as an alternative method. However, studies focusing on an alternative method to stimulate the rooting of cuttings of the lemon-Tahiti (Citrus latifolia Tanaka) are restricted. Therefore, the objective was to evaluate the effects of an alternative methods of the propagation of lemon-Tahiti rooting cuttings using of tiririca extract. The experimental design was randomized blocks based on five treatments and four replications each. The treatments consisted of control (cuttings treated with distilled water) and treatment of cuttings for four extracts of tiririca: $75 \mathrm{~g} / \mathrm{L}(25 \%), 150 \mathrm{~g} / \mathrm{L}$ $(50 \%), 225 \mathrm{~g} / \mathrm{L}(75 \%)$ e $300 \mathrm{~g} / \mathrm{L}(100 \%)$ concentrations. Each experimental unit consisted of six cuttings. Evaluations were conducted after 90 days of planting, and the parameters were measured considering: percentage the rooting of cuttings; number of roots by cuttings; length of the three largest roots by cuttings; percentage of callus cuttings; percentage of living cuttings; the percentage of dead cuttings; leaf quantity by cuttings; green mass $(\%)$ and dry mass $(\%)$. The extract of tiririca did not influence the rooting of cuttings of the lemon-Tahiti. Percentages of the live cuttings were significantly higher at $225 \mathrm{~g} / \mathrm{L}(75 \%)$, indicating that the extract did not have allelopathic effect on the development and survival of cuttings. However, studies are needed to verify the ideal concentration of the extract in the rooting of cuttings of the lemonTahiti. 


\section{INTRODUÇÃO}

As técnicas de propagação assexuada com o uso da estaquia podem ser usadas para a formação de indivíduos geneticamente idênticos à planta mãe, significando um avanço no estabelecimento do cultivo de plantas, sendo uma alternativa importante para o melhoramento genético da espécie (DINALLI et al., 2013; MENDONÇA et al., 2018).

$\mathrm{Na}$ estaquia, o principal aspecto determinante do sucesso da propagação é a indução do enraizamento adventício de porções destacadas da planta matriz, denominadas de estacas, que quando submetidas a condições favoráveis, originam uma nova planta completa (HARTMANN et al., 2011; XAVIER et al., 2013).

As plantas cítricas, compreendidas principalmente por laranjeiras, tangerineiras, limoeiros e limeiras, dentre outras, da família Rutaceae desempenham papel de acentuada importância socioeconômica em nível global. De origem tropical, o limão-Tahiti (Citrus latifolia Tanaka) não é um limão verdadeiro, mas uma lima ácida. Cultivado na Califórnia, EUA, admite-se que sua introdução tenha ocorrido a partir de sementes de frutos importados do Tahiti, originando assim a sua denominação (MARTINELLI, 2017).

Dentre os múltiplos usos do limão-Tahiti, o suco é usado na culinária, na limpeza e no preparo de alimentos. Na medicina, o fruto é utilizado no tratamento de gripes e deficiências de vitamina $\mathrm{C}$, dentre outros tratamentos. Além disso, o óleo essencial da casca do fruto é utilizado como fitoterápico. Análises físicas e químicas da farinha dos resíduos do limão-Tahiti e biscoitos enriquecidos por ela apresentaram consideráveis teores de fibra alimentar, lipídios e vitamina $\mathrm{C}$ (CÂMARA et al., 2017). Existem diversos clones de limãoTahiti disponíveis para a produção de estacas no Brasil, sendo as estacas produzidas a partir da seleção de cultivares.

As técnicas de propagação vegetativa associadas a uso de indutores de desenvolvimento incluem usualmente a aplicação de reguladores de crescimento, tais como, as auxinas e citocininas, que se utilizadas em concentrações adequadas podem potencializar o enraizamento e a formação da parte aérea da planta (LAFETÁ et al., 2016). As auxinas são as substâncias mais importantes na indução do enraizamento em estacas, podendo ser extraídas de plantas ou obtidas de forma sintética.

A espécie Cyperus rotundus L., popularmente conhecida como tiririca é uma planta daninha herbácea perene, que se multiplica por sementes e de forma vegetativa a partir de bulbos, tubérculos e rizomas subterrâneos, sendo caracterizada como uma das plantas invasoras de difícil controle em nível mundial, estando relacionada a grandes prejuízos em diversos agroecossistemas e muito conhecida por seus efeitos alelopáticos (PEREIRA et al., 2012; REZENDE et al., 2013).

Nos bulbos da tiririca são encontradas substâncias, hormônios, que favorecem a promoção de raízes. A tiririca apresenta nível elevado de ácido indol-3-butírico (AIB), um fitorregulador específico para formação de raízes das plantas (CREMONEZ et al., 2013).

Diversos estudos, tais como, realizados por Souza et al., (2012), Silva et al., (2016) e Farina (2017) têm demonstrado o efeito benéfico dos extratos aquosos de $C$. rotundus no enraizamento adventício de estacas de Solanum lycopersicum, Rubus sp. e Baccharis articulata, pois a espécie apresenta em seus tubérculos altas concentrações de auxinas.
Entretanto, ainda que os resultados obtidos com o uso do extrato de $C$. rotundus parecem ser promissores, são necessários novos estudos complementares, tais como, afirma Thiesen et al. (2019), a fim de demonstrar a utilidade agroecológica do extrato aquoso no enraizamento de estacas de plantas e cultivares, abrangendo as características fenológicas das espécies estudadas.

Esse estudo visou avaliar os efeitos de uma técnica alternativa de propagação de mudas de estacas de limão-Tahiti por meio de enraizamento, com o uso de extrato de tiririca.

\section{MATERIAL E MÉTODOS}

O experimento foi conduzido, durante o período de setembro de 2018 a janeiro de 2019, nas dependências da Universidade Estadual de Mato Grosso do Sul (UEMS), Unidade Universitária de Cassilândia (UUC), em Cassilândia, Mato Grosso do Sul, localizada na latitude de $19^{\circ} 14^{\prime} \mathrm{S}$, longitude de $51^{\circ} 53^{\prime} \mathrm{W}$ e altitude de $734 \mathrm{~m}$. A região de Cassilândia apresenta Clima Tropical Chuvoso (Aw) de acordo com a classificação climática de Köppen, com temperatura atmosférica média anual de $24,46{ }^{\circ} \mathrm{C}$ e precipitação pluvial média anual de 132,25 mm.

A preparação do extrato da tiririca e dos respectivos tratamentos para as estacas de limão-Tahiti (Citrus latifolia Tanaka) foram realizados no Laboratório de Química Ambiental e o experimento foi mantido em Casa de Vegetação.

$\mathrm{O}$ delineamento experimental utilizado foi o de blocos ao acaso, com cinco tratamentos e quatro repetições, sendo compostos por testemunhas (estacas tratadas com água destilada) e estacas tratadas com quatro extratos de tiririca, nas concentrações de $75 \mathrm{~g} / \mathrm{L}$ (25\%), $150 \mathrm{~g} / \mathrm{L}$ (50\%), $225 \mathrm{~g} / \mathrm{L}$ (75\%) e $300 \mathrm{~g} / \mathrm{L}(100 \%)$. Cada unidade experimental foi constituída por seis estacas. As estacas de limão-Tahiti utilizadas no experimento foram retiradas de ramos de fluxos vegetativos, de colorações verdes, com ausência de flores e frutificações, sendo as matrizes em bom estado fitossanitário e nutricional, de pomar orgânico de área rural.

As estacas de limão-Tahiti foram coletadas 24 horas antes de serem tratadas com as diferentes concentrações do extrato de tiririca, sendo feito um corte reto no ápice de cada estaca e outro em bisel na base, medindo aproximadamente de 10 a 15 $\mathrm{cm}$ de comprimento e mantidas em umidade até o início do experimento.

Os tubérculos de $C$. rotundus foram coletados nas proximidades da UEMS/UUC, também 24 horas antes do início do experimento e foram mantidos em geladeira. Para a preparação do extrato aquoso de tiririca (Figura 1), os tubérculos foram previamente isolados, lavados em água destilada, secos em papel toalha e pesados em balança analítica. Foram pesados 300 gramas de tubérculos limpos e triturados em $1000 \mathrm{~mL}$ de água destilada, com auxílio de um liquidificador. Os tubérculos triturados em água destilada foram filtrados, por meio de filtração simples, produzindo um extrato bruto a $300 \mathrm{~g} / \mathrm{L}(100 \%)$. Este extrato bruto a $300 \mathrm{~g} / \mathrm{L}$ (100\%) foi diluído em solução com água destilada nas seguintes concentrações de: $75 \mathrm{~g} / \mathrm{L}(25 \%), 150 \mathrm{~g} / \mathrm{L}(50 \%)$ e $225 \mathrm{~g} / \mathrm{L}$ (75\%), respectivamente. As diluições foram acondicionadas em frascos âmbar e mantidos a temperatura de $4^{\circ} \mathrm{C}$ até o momento do uso (SOUZA et al., 2012). 
Figura 1. Processamento do extrato de tiririca e seleção de estacas de limão-Tahiti no Laboratório de Química Ambiental da Universidade Estadual de Mato Grosso do Sul, Unidade Universitária de Cassilândia, Mato Grosso do Sul. A. Seleção das estacas de limão-Tahiti e extração dos tubérculos de tiririca. B. Tubérculos isolados em papel toalha. C. Tubérculos triturados em água destilada, filtragem e acondicionamento do extrato bruto de tiririca em frasco âmbar. D. Recipientes para estacas de limão-Tahiti nas diferentes concentrações de água destilada (0\%), $75 \mathrm{~g} / \mathrm{L}(25 \%), 150 \mathrm{~g} / \mathrm{L}(50 \%), 225 \mathrm{~g} / \mathrm{L}(75 \%)$ e $300 \mathrm{~g} / \mathrm{L}(100 \%)$.

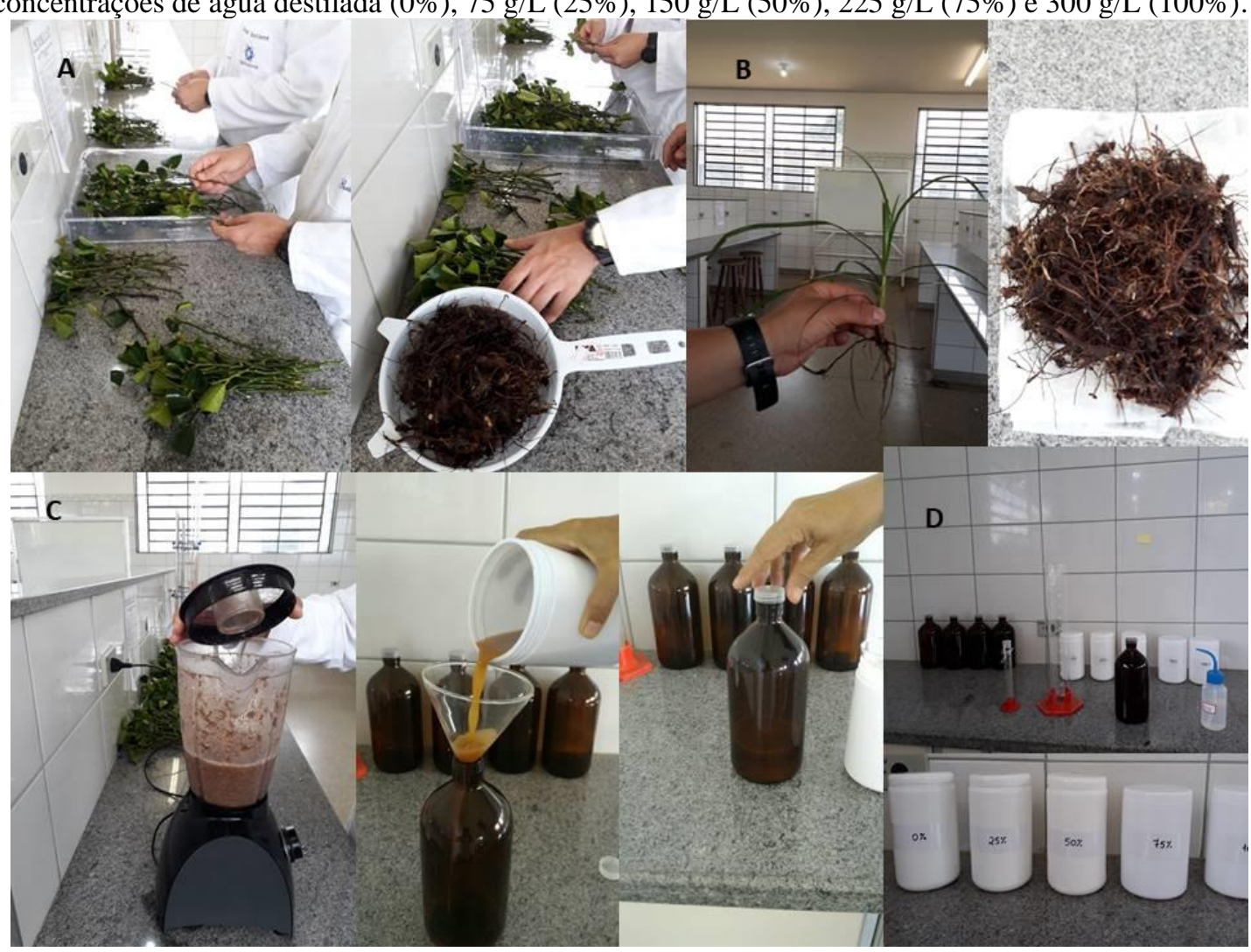

Assim, aproximadamente $5 \mathrm{~cm}$ da base das estacas de limão-Tahiti foram imersas durante um período de 24 horas em diferentes recipientes, previamente sanitizados e etiquetados. Após este período de 24 horas, as estacas de limão-Tahiti foram imediatamente plantadas em sacos plásticos, contendo substrato orgânico agroindustrial para plantas (Carolina Soil), sendo cerca de $2 / 3$ de seu comprimento, enterrado em posição vertical e mantidas sob sistema de irrigação por nebulização, diariamente.

Após cerca de 90 dias de cultivo, as estacas foram cuidadosamente retiradas do substrato, lavadas em água destilada e avaliados os seguintes parâmetros do enraizamento: porcentagem de estacas enraizadas (estacas vivas que emitiram raízes maiores que $1 \mathrm{~mm}$ ); número de raízes maiores que $1 \mathrm{~mm}$ por estaca; comprimento das três maiores raízes por estaca; porcentagem de estacas com calos (estacas que permaneceram vivas, não emitiram raízes e tiveram formação de calos); porcentagem de estacas não viáveis (estacas mortas e que não desenvolveram raízes ou calos). Além disso, foi avaliada a quantidade de folhas por estacas, a massa verde (g) e massa $\operatorname{seca}(\mathrm{g})$.

Os resultados foram submetidos à análise de variância (ANOVA), com auxílio do programa estatístico SISVAR ${ }^{\circledR}$ (FERREIRA, 2011), com médias comparadas pelo teste de Tukey a 5\% de probabilidade.

\section{RESULTADOS E DISCUSSÃO}

As Tabelas 1 e 2 apresentam os resultados obtidos para os valores médios dos cinco tratamentos, em que a maior porcentagem de estacas vivas $(90,10 \%)$ foi registrada para a concentração de $225 \mathrm{~g} / \mathrm{L}$ (75\%), quando comparado à testemunha. Assim, os menores percentuais de estacas mortas $(9,90 \%)$ foram observados para a concentração de $225 \mathrm{~g} / \mathrm{L}$ $(75 \%)$. Estes valores obtidos para estacas vivas e mortas foram significativos pelo Teste de Tukey a 5\% de probabilidade.

Entretanto, os resultados obtidos para as estacas vivas com raízes maiores que $1 \mathrm{~mm}(\%)$ e os percentuais de ocorrência de calos nas estacas vivas não apresentaram diferenças significativas pelo Teste de Tukey a 5\% de probabilidade para os tratamentos (Tabela 1).

Tabela 1. Estacas de limão-Tahiti tratadas com extrato de tiririca, sob diferentes concentrações. Estacas vivas (EV); estacas vivas, com raízes (EVCR); estacas vivas, com calos, sem raízes (EVCCSR); estacas mortas (EM).

\begin{tabular}{ccccc}
\hline Tratamentos & EV $(\%)$ & $\begin{array}{c}\text { EVCR } \\
>1 \mathrm{~mm} \\
(\%)\end{array}$ & $\begin{array}{c}\text { EVCCSR } \\
(\%)\end{array}$ & $\begin{array}{c}\text { EM } \\
(\%)\end{array}$ \\
\hline $0 \%$ & $84,00 \mathrm{ab}^{1}$ & $66,80 \mathrm{a}$ & $22,27 \mathrm{a}$ & $16,00 \mathrm{ab}$ \\
$25 \%$ & $66,70 \mathrm{~b}$ & $50,07 \mathrm{a}$ & $16,70 \mathrm{a}$ & $33,30 \mathrm{~b}$ \\
$50 \%$ & $81,32 \mathrm{ab}$ & $64,17 \mathrm{a}$ & $32,17 \mathrm{a}$ & $18,67 \mathrm{ab}$ \\
$75 \%$ & $90,10 \mathrm{a}$ & $50,07 \mathrm{a}$ & $27,80 \mathrm{a}$ & $9,90 \mathrm{a}$ \\
$100 \%$ & $72,30 \mathrm{ab}$ & $65,57 \mathrm{a}$ & $24,17 \mathrm{a}$ & $27,70 \mathrm{ab}$ \\
\hline $\mathrm{CV} \%$ & 10,47 & 16,18 & 36,03 & 27,64 \\
\hline
\end{tabular}

${ }^{1}$ Médias de quatro repetições, constituídas por seis estacas. Médias seguidas pelas mesmas letras minúsculas nas colunas, não diferem significativamente a $5 \%$ de probabilidade pelo teste de Tukey.

O número de raízes maiores que $1 \mathrm{~mm}$ por estaca e o comprimento das três maiores raízes por estaca $(\mathrm{mm})$ não 
diferiram significativamente para as concentrações de $75 \mathrm{~g} / \mathrm{L}$ (25\%), $150 \mathrm{~g} / \mathrm{L}$ (50\%), $225 \mathrm{~g} / \mathrm{L}$ (75\%) e $300 \mathrm{~g} / \mathrm{L}$ (100\%), em relação ao controle (Tabela 2 ). $\mathrm{O}$ número de folhas por estaca apresentou variações pouco relevantes entre os tratamentos. Maiores valores de massa verde (g) e massa seca $(\mathrm{g})$ foram registrados para o controle (água destilada) e para o tratamento com extrato de tiririca a $300 \mathrm{~g} / \mathrm{L}(100 \%)$, respectivamente (Tabela 2).

$\mathrm{O}$ extrato aquoso de tiririca não influenciou o enraizamento adventício das estacas de limão-Tahiti. Porém, os percentuais de estacas vivas com raízes maiores que $1 \mathrm{~mm}$, tratadas em água destilada (controle) foram de 66,80\%, com valores pouco relevantes em relação àquelas estacas tratadas em extrato de tiririca a $300 \mathrm{~g} / \mathrm{L}(100 \%)$ e $150 \mathrm{~g} / \mathrm{L}(50 \%)$, onde os percentuais foram de $65,57 \%$ e 64,17 , respectivamente. Além disso, os percentuais de estacas vivas $(90,10 \%)$ foram significativamente maiores para a concentração de $225 \mathrm{~g} / \mathrm{L}$ (75\%), indicando que o extrato aquoso de tiririca não exerceu um efeito alelopático sobre o desenvolvimento e sobrevivência das estacas de limão-Tahiti.

Tabela 2. Estacas de limão-Tahiti tratadas com extrato de tiririca, sob diferentes concentrações. Número de raízes maiores que $1 \mathrm{~mm}$ por estaca (NRM); comprimento das três maiores raízes por estaca (CMR); número de folhas por estaca (NF); massa verde (MV); massa seca (MS).

\begin{tabular}{cccccc}
\hline Tratamentos & NRM & CMR $(\mathrm{mm})$ & NF & MV $(\mathrm{g})$ & MS $(\mathrm{g})$ \\
\hline $0 \%$ & $3,67 \mathrm{a}^{1}$ & $142,30 \mathrm{a}$ & $5,67 \mathrm{a}$ & $15,42 \mathrm{a}$ & $9,47 \mathrm{a}$ \\
$25 \%$ & $3,32 \mathrm{a}$ & $100,90 \mathrm{a}$ & $4,67 \mathrm{a}$ & $10,02 \mathrm{c}$ & $5,62 \mathrm{~b}$ \\
$50 \%$ & $4,32 \mathrm{a}$ & $130,78 \mathrm{a}$ & $3,32 \mathrm{a}$ & $11,10 \mathrm{bc}$ & $6,10 \mathrm{~b}$ \\
$75 \%$ & $3,68 \mathrm{a}$ & $108,70 \mathrm{a}$ & $3,67 \mathrm{a}$ & $11,32 \mathrm{bc}$ & $6,10 \mathrm{~b}$ \\
$100 \%$ & $3,32 \mathrm{a}$ & $103,12 \mathrm{a}$ & $4,82 \mathrm{a}$ & $14,10 \mathrm{ab}$ & $7,50 \mathrm{ab}$ \\
\hline CV $\%$ & 9,50 & 8,41 & 19,64 & 12,18 & 14,04 \\
\hline
\end{tabular}

${ }^{1}$ Médias de quatro repetições, constituídas por seis estacas. Médias seguidas pelas mesmas letras minúsculas nas colunas, não diferem significativamente a $5 \%$ de probabilidade pelo teste de Tukey.

As raízes adventícias e as partes aéreas das estacas de limão-Tahiti apresentaram desenvolvimento eficiente em sistema de irrigação por nebulização. Neste estudo, o extrato aquoso de tiririca não influenciou o enraizamento adventício das estacas de limão-Tahiti, mas não exerceu um efeito alelopático sobre o desenvolvimento e sobrevivência das estacas de limão-Tahiti.

$\mathrm{O}$ efeito benéfico do extrato aquoso de tiririca para o enraizamento adventício de estacas tem sido demonstrado por diversos autores. Estudos realizados por Silva et al. (2016) indicaram o potencial do extrato de tubérculos de tiririca no enraizamento de estacas de amoreira-preta (Rubus sp.) na concentração de $250 \mathrm{~g} / \mathrm{l}(50 \%)$.

Moreira e Giglio (2012) utilizaram concentrações iniciais do extrato de tiririca de $333 \mathrm{~g} / \mathrm{L}$ (100\%) para o milho e o trigo, semelhantes a este estudo com estacas de limão-Tahiti (300 $\mathrm{g} / \mathrm{L})$, sendo que para o milho, o extrato de tiririca $(12,5 \%)$ influenciou positivamente no comprimento da raiz, para o trigo, o extrato de tiririca $(12,5 \%)$ teve resultados positivos na altura da parte aérea e no peso das plântulas, mas não apresentando efeitos no comprimento da raiz. Portanto, a mesma concentração de extrato de tiririca utilizada para duas espécies da família Poaceae, com características fisiológicas diferentes mostrou efeitos divergentes na rizogênese.

A rizogênese de estacas de Rosmarinus officinalis foi estudada por Oliveira et al. (2019), utilizando a solução obtida da trituração dos tubérculos de $C$. rotundus na proporção inicial de $200 \mathrm{~g} / \mathrm{L}$ (100\%), também próxima a utilizada neste estudo, sendo diluída em diferentes concentrações $10 \%, 25 \%, 50 \%$ e $75 \%$. A metodologia de irrigação das estacas com extrato aquoso de tiririca foi mais eficiente que o sistema de contato por imersão, sendo que a concentração $20 \mathrm{~g} / \mathrm{L}$ (10\%) de extrato foi o tratamento mais eficiente, principalmente no desenvolvimento de massa seca de toda planta e das raízes.

Em contrapartida, outros estudos, utilizaram soluções de tubérculos de tiririca mais diluídas, tais como, com estacas de canela-sassafrás, nas concentrações de 37,5 g/L (75\%) e 50 g/L (100\%) que proporcionaram melhores resultados no estudo de rizogênese (SILVA et al. 2015) e, ainda, o extrato de tiririca na diluição de $25 \mathrm{~g} / 1,5 \mathrm{~L}$, proporcionou a maior porcentagem de estacas enraizadas do pinhão-manso (Jatropha curcas), mas faz-se necessário maior número de pesquisas na área, com intuito de fornecer informações adequadas e concentrações do extrato aquoso que melhor respondam ao enraizamento (SOUZA et al., 2016). Também, o extrato aquoso obtido de tubérculos de tiririca $(2 \mathrm{~g} / 40 \mathrm{~mL}$ de cada solvente separadamente: metanol PA, etanol PA e água destilada) foi eficiente na promoção da rizogênese e promoveu uma porcentagem de enraizamento semelhante à solução de AIB $(1000 \mathrm{mg} / \mathrm{L})$ em folhas de Solanum lycopersicum (SOUZA et al., 2012).

Além disso, Oliveira et al. (2014) verificou que o mofumbo (Combretum leprosum Mart.), não se adequou ao processo de propagação por meio de estaquia, sendo necessários mais estudos com propagação vegetativa dessa espécie, mas a imersão em extrato de tiririca $5 \mathrm{~g} / \mathrm{L}(10 \%)$ promoveu melhores resultados de enraizamento.

Estudos com o extrato aquoso de tiririca de Thiesen et al. (2019) na concentração de 23,36 g/1,25 L promoveram resultados satisfatórios sobre o número de brotos e o comprimento de raízes, não diferindo estatisticamente dos hormônios vegetais sintéticos em estacas de videira (Vitis vinifera L. [var. Bordô e Niágara]) imersas por 24 horas no extrato, entretanto, a resposta foi diferente entre as variedades, não ocasionando incremento significativo de massa seca de raiz e de folhas. Assim, o extrato aquoso de tiririca promove o enraizamento de maneira semelhante aos hormônios vegetais sintéticos e torna-se alternativa sustentável para o enraizamento de estacas de videiras, mas mais estudos são necessários quanto à concentração do extrato e à cultura a ser utilizada. Por outro lado, Koefender et al. (2017) constataram que a concentração de $100 \mathrm{~g} / \mathrm{L}(100 \%)$ de extrato de tiririca e o tempo de 10 minutos de imersão, proporcionaram melhor crescimento e desenvolvimento de estacas de fisális (Physalis angulata L.).

Nesse contexto, para uma mesma espécie de planta ou cultura é fundamental observar as concentrações iniciais do extrato aquoso de tiririca para verificar o ajuste da dose ideal 
desse bioestimulante natural da rizogênese, evitando efeitos alelopáticos que possam inibir o desenvolvimento e a sobrevivência das estacas, sendo necessários mais pesquisas experimentais.

Portanto, diversos autores afirmaram sobre a necessidade de realização de mais estudos para ajustar as concentrações do extrato de tiririca no enraizamento eficiente de estacas. Rezende et al. (2013) verificaram que a aplicação de extratos de folhas e de tubérculos de $C$. rotundus não influenciou o enraizamento de estacas de Duranta repens nos períodos de avaliação. Dias et al. (2012) relataram que o extrato de tubérculos de tiririca (tratamentos 0; 400; 800 e $1200 \mathrm{~g} \mathrm{dm}^{-3}$, por um período de 20 e 120 segundos) não se constituíram em uma alternativa viável para o enraizamento de estacas de cafeeiro.

Além disso, Batista et al. (2015) relataram também que o extrato de tiririca nas diluições $25 \%, 50 \%$ e $100 \%$ (20 g de tubérculos para $400 \mathrm{~mL}$ ) não apresentou influência no enraizamento de estacas herbáceas de Hyptis marrubioides (hortelã-do-campo). O extrato aquoso da parte aérea e sistema radicular em concentrações de $25 \%, 50 \%$ e $75 \%$ e $100 \%$ (25 g da parte aérea e $25 \mathrm{~g}$ de sistema radicular em $250 \mathrm{ml}$ de água) não promoveu o enraizamento de estacas lenhosas de pessegueiro cv. 'Chimarrita' no período de 90 dias (SCARIOT et al., 2017). Binsfeld et al. (2019) utilizaram a concentração de $50 \mathrm{~g} \cdot \mathrm{dm}^{-3}$ do extrato de tiririca, aplicando por imersão da base das estacas de pitaya (Hylocereus undatus), durante o período de 10 minutos, porém, não foi eficiente para o desenvolvimento das estacas de pitaya.

Similarmente, Pereira et al. (2012) verificaram que as concentrações $50 \%, 75 \%$ e $100 \%$ (33,33 g de tubérculos ou bulbos basais para $500 \mathrm{~mL}$ de solução hidroalcóolica) do extrato hidroalcóolico testadas, não influenciaram o enraizamento de estacas de maracujazeiro amarelo (Passiflora edulis Sims f. flavicarpa). Farina (2017) constatou que as concentrações testadas do extrato aquoso de tiririca nas concentrações de $25 \% \quad 50 \%$ e $100 \%$ (2 g/40 mL) não influenciaram o enraizamento das duas espécies de carqueja (Baccharis trimera e Baccharis articulata), mas efeitos significativos foram observados para $B$. trimera tratada com o extrato homeopático de tiririca (extrato homeopático preparado a partir de $50 \mathrm{~g}$ de tubérculos triturados e adicionados a um Erlenmeyer, contendo álcool 70\%).

Esses estudos demonstram uma ampla variação de resultados quando se trata da interação de extrato de tiririca com diferentes espécies de plantas, apresentando ciclos de vidas, aspectos fenológicos e características fisiológicas diversificadas.

\section{CONCLUSÕES}

$\mathrm{O}$ extrato aquoso de tiririca não influenciou o enraizamento adventício das estacas de limão-Tahiti, porém, não exerceu um efeito alelopático sobre o desenvolvimento e a sobrevivência das estacas de limão-Tahiti.

\section{REFERÊNCIAS}

BATISTA, J. A.; BOTREL, P. P.; FIGUEIREDO, F. C. Efeito do extrato de tiririca e bioestimulante no enraizamento de estacas de Hyptis marrubioides Epl. Revista Agrogeoambiental, v.7, n.2, p.91-99, 2015. 10.18406/2316$1817 \mathrm{v} 7 \mathrm{n} 22015685$.
BINSFELD, M. C.; SCHWAB, N. T.; BOTH, V.; BUFFON, P. A.; FÜHR, A.; RAMPAZZO, J. C.; PICIO, M. D. Enraizadores alternativos na propagação vegetativa de pitaya. Magistra, v.30, p.251-258, 2019.

CÂMARA, P. F.; RIBEIRO, C. F. A.; BARBOSA, R. S.; ZUNIGA, A. D. G.; RIBEIRO, S. C. A.; CÂMARA, U. B. B.; RODRIGUES, E. B. S. Farinha obtida dos resíduos de limão Tahiti para enriquecimento de biscoitos. Revista Brasileira de Produtos Agroindustriais, v.19, n.2, p.131-138, 2017.

CREMONEZ, F. E.; CREMONEZ, P. A.; CAMARGO, M. P.; FEIDEN, A. Principais plantas com potencial alelopático encontradas nos sistemas agrícolas brasileiros. Acta Iguazu, v.2, Suplemento, p.70-88, 2013.

DIAS, J. R. M.; SILVA, E. D. A.; GONÇALVES, G. S.; SILVA, J. F.; SOUZA, E. F. M.; FERREIRA, E.; STACHIW, R. Enraizamento de estacas de cafeeiro imersas em extrato aquoso de tiririca. Coffee Science, v.7, n.3, p.259-266, 2012. 10.25186/cs.v7i3.358.

DINALli, R. P.; CASTILHO, R. M. M.; GAZOLA, R. N.; CELESTRINO, T. S.; GONZAGA, D. A.; FERREIRA, A. F. A. Produção de mudas de Zamioculcas zamiifolia por estaca foliar. Tecnologia \& Ciências Agropecuária, v.7, n.3, p.7-12, 2013.

FARINA, V. A. Indução ao enraizamento adventício de espécies do gênero Baccharis submetidas ao tratamento com extratos de bulbos de Cyperus rotundus. 2017. 80f. Dissertação (Mestrado em Agroecologia e Desenvolvimento Rural Sustentável) - Universidade Federal da Fronteira Sul, Laranjeiras do Sul. 2017.

FERREIRA, D. F. Sisvar: a computer statistical analysis system. Ciência e Agrotecnologia, Lavras, v.35, n.6, p.10391042, 2011.

HARTMANN, H. T.; KESTER, D. E.; DAVIES JUNIOR, F. T.; GENEVE, R. L. Plant propagation: principles and practices. 8.ed. New Jersey: Englewood Clipps. 2011, 915p.

KOEFENDER, J.; SCHOFFEL, A.; CAMERA, J. N.; BORTOLOTTO, R. P.; PEREIRA, A. P.; GOLLE, D. P.; HORN, R. C. Concentração de extrato de tiririca e tempo de imersão no enraizamento de estacas de fisális. Holos, v.05, p. 17-26, 2017. 10.15628/holos.2017.6264.

LAFETÁ, B. O.; DE MATOS, M. P.; LAGE, P.; FERRARO, A. C.; PENIDO, T. M. A. Ácido indol-3-butírico (AIB) no enraizamento de estacas de fedegoso gigante. Pesquisa Florestal Brasileira, v.36, n.88, p.489-496, 2016. 10.4336/2016.pfb.36.88.1084.

MARTINELLI, R. Mulch de braquiária (Urochloa spp.): opção de manejo integrado de plantas daninhas em citros. 2017. 75f. Dissertação (Mestrado em Agricultura Tropical e Subtropical) - Instituto Agronômico de Campinas, Campinas. 2017. 
MENDONÇA, L. P.; BATISTA, J. N.; MAGALHÃES, W. B.; FERREIRA, J. P.; BUCHER, C. A. Ácido-indol-3-butirico e época de coleta influenciando no enraizamento de Odontonema strictum (Nees) O. Kuntze. Revista Brasileira de Engenharia de Biossistemas, v.12, n.2, p.176-184, 2018. 10.18011/bioeng2018v12n2p176-184.

MOREIRA, G. C.; GIGLIO, L. C. Uso de extrato de tiririca em sementes de milho e trigo. Cultivando o Saber, v.5, n.3, p.8999, 2012.

OLIVEIRA, D. M.; RIBEIRO, M. C. C.; BENEDITO, C. P.; PAIVA, E. P.; SÁ, F. V. S. Estaquia para propagação vegetativa do mofumbo. Revista Verde de Agroecologia e Desenvolvimento Sustentável, v.9, n.1, p.163-167, 2014.

OLIVEIRA, K. M.; RIBEIRO, J. S.; BONETT, L. P.; CRUZ, R. M. S. Influência do extrato aquoso de Cyperus rotundus L. na rizogênese de Rosmarinus officinalis L. Arquivos de Ciências Veterinárias e Zoologia, v.22, n.1, p.27-32, 2019. 10.25110/arqvet.v22i1.2019.7328.

PEREIRA, E. O.; LOPES, J. C.; MARÇAL, T. S.; COELHO, R. I. Enraizamento de estacas de maracujazeiro cultivadas em diferentes substratos e tratadas com extratos de tiririca. Nucleus, v.9, n.2, p.93-102, 2012. 10.3738/nucleus.v9i2.722.

REZENDE, F. P. F.; ZUFFELLATO-RIBAS, K. C.; KOEHLER, H. S. Aplicação de extratos de folhas e tubérculos de Cyperus rotundus L. e de auxinas sintéticas na estaquia caulinar de Duranta repens L. Revista Brasileira de Plantas Medicinais, v.15, n.4, Suplemento I, p.639-645, 2013. $\underline{10.1590 / \mathrm{S} 1516-05722013000500003}$.

SCARIOT, E.; BONOME, L. T. S.; BITTENCOURT, H. V. H.; LIMA, C. S. M. Extrato aquoso de Cyperus rotundus no enraizamento de estacas lenhosas de Prunus persica cv. 'Chimarrita'. Revista de Ciências Agroveterinárias, v.16, n.2, p.195-200, 2017. 10.5965/223811711622017195.

SILVA, L. C. S.; NOGUEIRA, P.; SEGATTO, C.; BORTOLOTTI, F. L.; LAJÚS, C. R.; LUZ, G. L. Rizogênese das estacas de canela-sassafrás (Ocotea odorifera (Vellozo) Rohwer) através da utilização de fitohormônio. Revista Científica Eletrônica de Agronomia, n.28, Periódico Semestral, p.51-58, 2015.

SILVA, A. B.; MELLO, M. R. F.; SENA, A. R.; FILHO, R. M. L.; LEITE, T. C. C. Efeito do extrato de Cyperus rotundus L. no enraizamento de estacas de amoreira-preta. Revista Cientec, v.8, n.1, p.1-9, 2016.

SOUZA, M. F.; PEREIRA, E. O.; MARTINS, M. Q.; COELHO, R. I.; JUNIOR, O. S. P. Efeito do extrato de Cyperus rotundus na rizogênese. Revista de Ciências Agrárias, v.35, n.1, p.157-162, 2012.

SOUZA, L. H.; CALANDRELLI, L. L.; GONZALES, J. L. Efeito do extrato aquoso de tubérculos de Cyperus rotundus L. na propagação por estaquia Jatropha curcas L. Revista de Investigaciones Altoandinas, v.18, n.1, p.09-18, 2016. $\underline{10.18271 / \text { ria.2016.173. }}$.

THIESEN, L. A.; SCHMIDT, D.; HOLZ, E.; ALTISSIMO, B. S.; PINHEIRO, M. V. M.; HOLZ, E. Viabilidade do extrato aquoso de Cyperus rotundus como indutor de enraizamento em estacas de videira em comparação com hormônios sintéticos. Acta Biológica Catarinense, v.6, n.3, p.14-22, 2019. 10.21726/abc.v6i3.521.

XAVIER, A.; WENDLING, I.; SILVA, R. L. Silvicultura Clonal: Princípios e Técnicas. 2.ed. Viçosa: UFV, 2013. 279p. 